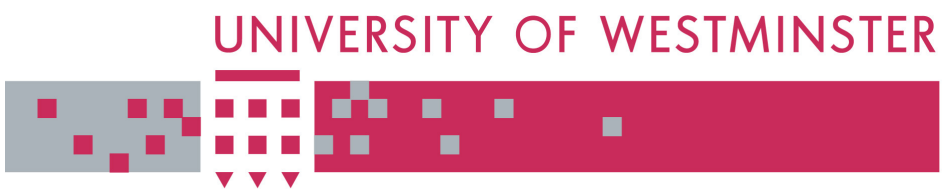

WestminsterResearch

http://www.wmin.ac.uk/westminsterresearch

\title{
Regulation for survival: training and skills in the construction labour market in Jersey, Channel Islands.
}

\section{Sepideh Arkani}

Linda Clarke

Elisabeth Michielsens

Westminster Business School

This is an electronic version of an article published in the Journal of Vocational Education and Training, 55 (3). pp. 261-279, September 2003. Journal of Vocational Education and Training is available online at:

http://www.journalsonline.tandf.co.uk/openurl.asp?genre=article\&issn=1363$6820 \&$ volume $=55 \&$ issue $=3 \&$ spage $=261$

The WestminsterResearch online digital archive at the University of Westminster aims to make the research output of the University available to a wider audience. Copyright and Moral Rights remain with the authors and/or copyright owners. Users are permitted to download and/or print one copy for non-commercial private study or research. Further distribution and any use of material from within this archive for profit-making enterprises or for commercial gain is strictly forbidden.

Whilst further distribution of specific materials from within this archive is forbidden, you may freely distribute the URL of WestminsterResearch.

(http://www.wmin.ac.uk/westminsterresearch).

In case of abuse or copyright appearing without permission e-mail wattsn@wmin.ac.uk. 


\section{Regulation for survival: Training and skills in the construction labour market in Jersey, Channel Islands}

14/11/03

word count: 7,220 (including title page and references)

Correspondence address:

Professor Linda Clarke

Westminster Business School

University of Westminster

35 Marylebone Road

London NW1 5LS

Tel.: 02079115000 ext. 3158

E-mail: clarkel@wmin.ac.uk 


\begin{abstract}
:
There is a crisis in the vocational training provision of the Channel Island of Jersey's construction industry that has similarities with the British situation. Unavailability and inappropriateness of skills, the non-viability of current training and recruitment policies on the island, the fragmentation of the training infrastructure, the demand-driven and task- or job-specific nature of training, the Jersey-born and male focus of recruitment and the uncoordinated, traditional and short-term approach of the local construction industry towards promotion and financing of training provision were found to be working against the industry's long-term needs and restricting its ability to respond to the variability of the production process. In contrast, a structured training policy incorporating the needs of both education and industry (employee and employer) and holding a long-term vision should enable the construction industry of Jersey to reverse the downward spiral.
\end{abstract}




\section{Introduction}

At a time when government seeks to import nurses, teachers and other professionals, and considers whether to extend this to particular categories of skilled workers, the question of immigration as an alternative to extending the training system has come to the fore. In neo-classical terms, where the market is allowed to regulate itself, training too should take care of itself and, if skill shortages develop, then importing the necessary skills is the obvious solution. In contrast, within a more state-regulated system the labour market is structured and a training infrastructure is developed to meet its requirements. This paper addresses the importance of developing skills as a long-term strategy. While importing skills may be seen as beneficial in the short-term, in the long term the benefits for the development of the industry are more questionable. The example of the crisis in training and skills provision in the Channel Island of Jersey's construction industry is ideal to support the case for regulation. In illustrating the problems associated with a low skills equilibrium it is especially apposite, particularly as these bear a remarkable similarity to those in the UK construction industry (Finegold \& Soskice, 1988). The island therefore provides a useful comparison, one that, due to the small size of the labour market and its bounded character, is much more accessible and analysable, presenting potential solutions of relevance for the UK.

The paper shows how the predominant problems facing the construction industry in Jersey are: the lack of a structured, integrated policy for training and the absence of comprehensive training infrastructure contributing in turn to low levels of productivity and efficiency and high building costs. No amount of immigration is going to alter this. The solution suggested instead is a more regulated and coherent long-term policy for skill 
improvement, that is greater investment in the labour force, as a basis for improving productivity in the industry.

The data presented on the Jersey construction sector were collected during 2000 as part of an overall construction sector skills audit and training analysis conducted for the Jersey (States) Training and Enterprise Partnership (TEP), which is responsible for overseeing industry-based vocational training on the island. Detailed face-to-face interviews (in total 73) were conducted with trade apprentices, professional trainees, employees, employers and key players from industry, various departments of the States of Jersey, the Further Education College and professional and trade union organisations. The interviews were semi-structured and took between 1-2 hours to complete. The employers interviewed tended to be skewed towards (larger) employers who train and included professional employers, contractors, trade employers and managers of utility companies and of an engineering firm, and covered the following themes: training; skills; recruitment; retention; employment and working conditions and future prospects in particular occupations, firms and the industry. (See Arkani et al. (2001) for a full overview of methodology and data.) Information derived from the interviews was complemented with: official documents and reports of various government departments; Jersey-specific employment and training data sets (e.g. Policy and Resources Department, 2000a/b); and statistical information such as the 1996 and 2001 Jersey Census (e.g. Etat Civil Committee, 1997/2002).

"Regulation" as an alternative to the continuance of an unregulated labour market is not understood simply as "control" or as the introduction of a new set of rules or laws, but in 
the broader sense first elaborated by the French regulation school (e.g. Boyer, 1987;

Boyer \& Saillard, 2002; Benko \& Lipietz, 1998). In this respect "regulation" signifies a "group of institutionalised rules", that is, rules embedded in a structured institutional framework, whether local or at state level, that determine, orchestrate or bound relations between capital and labour prevailing in a territory. Indeed, it is through regulation that the structure of the labour market, relations between capital and labour and the prevailing set of institutions are limited and achieve their dynamic. In the absence of a system of regulation in this sense, the labour market and relations between capital and labour become or appear fragmented, arbitrarily linked to state institutions and thus unresponsive or unpredictably responding to local or state policies.

\section{Jersey: structure and governance}

The Channel Island of Jersey is linked to Britain in being a crown protectorate in the Queen's capacity as Duke of Normandy. It is not part of the UK as such, or indeed of the EU, and its laws, policies and practices are ostensibly of its own making and have to be endorsed by the States of Jersey. The governmental system is highly fragmented, based on a States Assembly and a complex committee system (see Figure 1). The Assembly of the States passes laws, approves the annual budget of public expenditure, determines policy on propositions presented by committees or individual members, debates issues of public importance and represents the people of Jersey.

[FIGURE 1 NEAR HERE] 
While the legislative system operates relatively autonomously, the necessity of approximating to UK (and even to EU) policies is acknowledged on the island, not only because of extensive interaction in all domains but also because the labour market itself is not completely insular. Still, important differences remain. Employment legislation is minimal, with no employment protection, no specific employment arbitration system or requirement for equality. Jersey's Norman past has meant that the legislative system derives from both Norman law and insular Jersey law and the parties have a choice between the two in considering the most advantageous route for trial. Recruitment is regulated, however, and is intended to make as good a use as possible of the indigenous Jersey labour force by promoting the recruitment of locals above non-locals (Industries Committee, 1999). While there are no visa requirements for EU nationals, housing legislation strictly regulates the type of accommodation non-Jersey-born are entitled to when living on the island, which influences non-island recruitment patterns as well. Only long residency (19 years) will give non-Jersey-born (and Jersey-born who have moved abroad for a certain time) a right to "qualified housing". The Jersey legislative system has, however, come under increasing criticism. Changes are seen to be necessary to "encourage the effective use of manpower on the island while ensuring social justice" and "to enhance Jersey's place in the international business arena" (Department of Employment and Social Security, 1999). The proposed changes include unfair dismissal protection, minimum wages, trade union involvement and dispute resolution amongst others.

The most distinguishing feature of the Jersey labour market is the small size of the available workforce. Of a population of 87,186 in $2001,46,590$ were economically 
active. Jersey differs from the UK in terms of the relative importance of certain industries. The importance of the service industry has to be noted, in particular the finance and legal sector ( $25 \%$ compared to $5 \%$ in UK). Other sectors with a higher share of employment than the UK include hotels and restaurants (7\% compared to 4\%) and construction (9\% compared to $7 \%$ ). Manufacturing (3\% in comparison to $17 \%$ in the UK) is hardly found on the island (ONS, 2001; Etat Civil Committee, 2002).

\section{Vocational training in Jersey: the example of construction training}

The structure of the training system follows the UK example: the National Vocational Qualification (NVQ) system has been adopted, just as was the City and Guilds system before it. Higher education is not provided on the island, so school leavers attend British universities. Educational attainment in Jersey differs from the UK: $11 \%$ of the working age population has reached degree level (16\% in UK), but $34 \%$ (36\% for non Jersey born) have no formal qualifications (16\% in UK) (Etat Civil Committee, 2002).

The vocational training framework is built around the interaction of industry (employers), the only island-specific further education college and the TEP or Training and Enterprise Partnership (responsible for employment-related training). Education and "training related to employment" are, however, organisationally split. The former falls under the remit of the Education Committee, the latter under the Employment and Social Security Committee.

Highlands College (which falls under the Education Committee) is the only provider of construction trade training. Construction trade training leads to NVQ Level 3 or fully- 
skilled craft status, but has the benefit of a full-time foundation start year based on the German model in which trainees try out a number of trades. This is followed by a minimum of two years on day release to achieve NVQ2 and one further year for NVQ3.

In the last two decades a widespread reduction in trainee intake into the Jersey construction industry has taken place, resulting in significant trade skill shortages as expressed in rising numbers of unfilled vacancies (Policy and Resources Department 2000a). This phenomenon is also visible in the US (Salzman, 1998), Australia (Toner, 2000) and the UK (Clarke \& Wall, 1998a), although not in other mainland European countries, especially the Netherlands, where there has been a significant increase in the number of trainees. Reductions in the intake of trainees have important implications for industry investment and economic and job growth opportunities, as well as for the introduction of new technologies (Marsden, 1995). The situation in Jersey, which relies exclusively on apprenticeship, is particularly severe, even in comparison with the UK. For construction, there are around 18-20 entrants to the full-time foundation course each year, representing only $1.4 \%$ of those engaged in construction, a very low rate, particularly compared with European countries such as Germany, the Netherlands and Denmark where trainee rates in particular trades are estimated at $24 \%, 9 \%$ and $18 \%$ of skilled workers respectively (Clarke \& Wall, 2000). It is also a far lower rate than for Britain, where construction trainees represent approximately $6 \%$ of construction employees, though of these the proportion of Modern Apprentice first-year entrants is low, at $2.8 \%$ (CITB, 2002). The severity of the situation however begs additional clarification - including the size limitation of the Jersey labour market and the effect of 
the attraction of the financial sector on other sectors and on the cost of living on the island.

The decline in apprenticeships in Britain has been a well-researched topic (Marsden, 1995; Clarke \& Wall, 1998a; Steedman, 1998; Toner, 2000). Supply side factors are one important reason, the fact that the training provided may be unattractive, outdated and irrelevant. Demand side explanations, including the structural characteristics of the sector, are another important contributor to training failure (Steedman, 1998). Construction training in Jersey faces a number of these problems which can be largely attributable to the lack of a structured, formal and comprehensive policy for vocational construction training - and, for that matter, employment - that takes into account the long-term needs of the different actors (education and industry) and the long-term skill, education and employment needs of the island as a whole. In other words, it is precisely the lack of regulation that lies at the core of the training problem, posing the question of whether training can indeed be effective without a more structured, integrated and regulated approach (Stevens, 1999). Our interviews revealed the dissatisfaction of employers and key players with the lack of an overall plan for training in Jersey, with clear strategic aims and pragmatic objectives in which all involved agencies take a different but complementary role.

One key problem with the training system in Jersey is that it is - as in the UK - demand driven and employer based. The apprenticeship scheme as a result relies exclusively on the goodwill of individual employers to take on apprentices, which means that firms' involvement in training varies considerably. Training is informal rather than structured, 
the skills imparted may be narrowly firm-specific. Construction training therefore falls onto a restricted number of "good practice" employers who take on apprentices on a regular basis, out of traditional objectives (firms with a long history of apprenticeship training) or because they see it as the only way of securing the future workforce. These firms tend to employ a core of experienced, skilled workers on a long-term basis who supervise the apprentices. Next to these, there are a significant number of firms that are not interested in taking on apprentices. Several apprentices reported that they found it difficult to find an apprenticeship even with the help of Highlands College. When taken on, the "apprentice" is defined as an "employee" and is seen as part of the workforce. This is acknowledged in Jersey's legislation and in workforce quotas, and was apparent in our interviews. Senior apprentices admitted supervising junior apprentices and apprentices were kept from day release when there was too much work on site. The lack of a separate status for a construction apprentice is related to the lack of investment and commitment to training. Employers were largely unaware of the overall performance of their apprentices, the maximum time left in their training and the administrative tasks that have to be done by themselves or the apprentice for training and funding purposes.

A second problem with the system is that the focus of the island is in effect on education rather than vocational training, as indicated by the larger proportion of pupils going into higher education each year (80\%) versus the smaller proportion going into vocational training. This has justified and contributed to the prioritisation of education over training in terms of both policy and financial support (Education Department, 1998). However, under-investment in vocational training could be seen as a factor in the lower numbers of skilled craft workers on the island: only $14 \%$ (compared with $17 \%$ in the UK) of the 
Jersey workforce has a "skilled craft or related" occupation (Jersey Employers' Survey, 2000; Richter, 1998). This indicates that even though the proportion of those employed in the sector of construction in Jersey is relatively higher than that in the UK, a disproportionately lower number are skilled or in a "craft" occupation. In the UK, the proportion of the construction workforce classified as labourers as opposed to skilled workers is anyway already much higher than other leading European countries (Clarke \& Wall, 2000). Improvements in productivity invariably go hand in hand with a reduction in labour intensity, in the proportion of untrained labourers. To achieve this therefore implies increasing the States' provision of vocational education and training for construction and ensuring that this is integrated with the construction labour market.

A third training problem refers to the suitability of NVQ skills delivery in Jersey.

The apprenticeship programme is currently being reviewed because the NVQ system turned out to be a nightmare. (trade association)

The implementation of the NVQ qualification system has the advantage of linking to the UK framework but the disadvantages of being too narrowly based, divorced from the training process as such, attached to output-based funding, and containing insufficient underpinning knowledge. Keep \& Mayhew (1999) argue that the approaches adopted to skills delivery in the UK, particularly in terms of NVQ qualifications (therefore also relevant to Jersey), tend to emphasize task-specific aspects and softer interpersonal capabilities rather than theoretical knowledge and hard, technical expertise. The underlying focus of such a training policy is not on providing a broad basis to equip trainees for a working life, but on bringing them up to an operational standard in their chosen occupation within as short a time as possible (Steedman, 1998). Research on 
construction industry training has shown that this short-term approach is especially pronounced in this sector, at least in the UK (Clarke \& Wall, 1998a). For the restricted Jersey construction labour market such a principle is disastrous because of the need for a broad spectrum of transferable skills in order to complete a range of tasks.

To build a tank in this firm two people are needed; in the UK it would be fifteen because of the high specification. (employer)

A significant number of interviewees, therefore, preferred the old City and Guilds to NVQ qualifications in terms of the standard of training, organisation and transparency.

In terms of training related to trades, emphasis must be on teaching a range of associated works rather than overall works. I am not a supporter of NVQ and prefer City and Guilds. The latter focuses more on giving people pride in their trade through on the job training from a knowledgeable person like a foreman. (key player)

\section{The nature of employment in construction}

Problems specifically related to the training structure are amplified by the traditional nature and fragmentation of the Jersey construction industry through the organisation of contractors and subcontractors and the large number of self-employed. Self-employment has increased significantly in the construction trades during the last two decades mirroring the situation in the UK, to reach $35 \%$ in 2001 compared with $11 \%$ for the overall Jersey workforce (Etat Civil Committee, 2002). As apparent from research on the UK construction industry, self-employment has a devastating effect on levels of training and is a critical factor in explaining low levels of training for the construction sector (e.g. Clarke \& Wall, 1998a). Unless regulated, in particular through controls on labour-only 
subcontracting, as applied in other European countries, its widespread use can also deter innovation and the successful functioning of any training levy system.

Another aspect of fragmentation on Jersey's construction sector self-employment is the fact that work is organised in small firms; even the largest firm (58 employees) would be considered small elsewhere in Europe. The Manpower Survey of December $1999^{1}$ recorded 765 employers in the Jersey construction sector (including one-person firms), that is $18 \%$ of the total $(4,291)$ for $10 \%$ of the total Jersey workforce; $60 \%$ of these are employed in establishments of fewer than 20 people (Policy and Resources Department, 2000b). Employers in the financial mediation and legal activities sectors on the other hand account for $4 \%$ (177) of all employers, though their workforce is $28 \%$ of the total Jersey labour force.

The increased importance of small firms in construction is not only in sharp contradiction to the increased requirement for sufficiently flexible and knowledge-based skills in the industry, but at the same time diminishes the capability to develop these skills, reducing productivity and increasing production costs. The job-specific nature of learning in smaller firms has the adverse effect on tradespersons of not being able to "identify and correct faults in the work of other tradespersons; and finding it difficult to adapt if conditions or specifications differ across projects" (Toner, 2000). Going together with

\footnotetext{
${ }^{1}$ For comparisons over sectors the December 1999 data are used, whilst for comparisons within construction the latest data (06/2000) are used. The total number of employers in construction in June 2000 is calculated as 790 (Table 2).
} 
fragmentation of organisation is a fragmentation of skills. The narrow skills focus and task-bound nature of the NVQ qualification system exacerbates this problem. Larger firms are more likely to train and have greater capacity, employing a wider range of occupations (Clarke \& Wall, 1998a). This was indicated also by the relatively large firms that we interviewed and is confirmed by Toner (2000): "The proportion of firms providing structured training is 6.6 times greater in larger firms than smaller firms".

The fragmented nature of the industry in both the UK and Jersey, coupled with the employer-based training system, has a severely negative impact on the level of training investment. Employers see training cost in terms of competitive disadvantage and are less inclined to invest in training when the return appears low. To increase training commitment and avoid a decline in training levels, a coordinated training framework is more effective in which the cost is shared by all. As Marsden (1995) states in relation to the UK training system: "Over the long run it is necessary to have effective cost sharing or participation by all employers in training so that none suffers competitive disadvantage. .... At the heart of the problem [with the UK apprentice system] has been a failure to ensure adequate regulation and a consistency of quality of apprenticeship training and to keep down its cost to employers."

Next to fragmentation, the traditional, informal and passive nature of the construction industry poses problems: in an attempt to tackle the problem of a limited labour market, overall flexibility and diversity (such as part-time work and the inclusion of women) have been promoted by the States of Jersey in its locally-focused employment policy. Jersey has a higher integration of women in the labour market than UK, with a higher overall 
female participation rate ( $76 \%$ compared with $72 \%$ in UK) and higher rate of women working full time (only a quarter of Jersey women work part time, compared with $43 \%$ in UK) (Etat Civil Committee, 2002). This integration however is not noticeable in the construction sector and in certain areas is lower than the UK. In the UK $10.4 \%$ of the construction workforce in 1996 was female, in Jersey 3.7\% (Etat Civil Committee, 1997; ONS, 1996). If only core construction activities are taken into account, such as skilled manual work or the construction professions, the integration of women in UK construction is however much lower ( $1 \%$ for construction trades; $8.5 \%$ for membership of the Institute of British Architects) (Fielden et al., 2000; Michielsens, Clarke \& Wall, 1997). The Jersey figures, however, show an even lower percentage $(0.4 \%$ in the construction trades), indicating the very traditional nature of the sector.

Training problems in the Jersey construction industry are coupled with severe recruitment and retention problems over the last five years. From the numbers of those undertaking apprenticeships (about 60) and the number of vacancies in construction firms at the moment (414), it is apparent that the industry cannot rely entirely on its traditional recruitment base. Advertisements are placed - whether for professional or manual workers - but in many cases no response is received. The majority of firms, including the professional firms, have unfilled vacancies and the non-availability of specialist trade workers creates an urgent problem. It is an eerie experience going around an almost deserted joinery workshop with machines lying idle even though work is available. Taking on apprentices was seen by several employers as the only way to recruit new workers on a long-term basis. But the potential recruitment base as seen by employers is exclusively male and young. 
The traditional and passive nature of the industry and its working and recruitment practices present obstacles to a drastic change in policy. There is no proactive innovative promotion and recruitment policy for construction on the part of industry, the Careers Service in schools or Highlands College to improve, for instance, equal opportunities in construction (Michielsens et al., 1997). The Careers Service in schools and at Highlands College is focused on continuing a routine package of activities, with little attention given to targeting new groups (e.g. girls, retrainers) and new projects; the first steps are expected to be taken by industry. In order for industry to recruit more apprentices into the sector, it would be necessary to work with the established Careers Service in a more coordinated way, involving teachers, parents and the students and looking towards new recruitment groups and ways such as: expanding the target group of secondary school leavers to include both boys and girls; providing other forms of training if apprentice places with employers cannot be found; attracting older recruits through adult and retraining courses; reducing the obstacles to return to Jersey after off-island long-term training and/or work experience (the 2001 census data showed that only $5 \%$ of all immigrants, that is arrivals since 1996, were originally Jersey born) and reducing the obstacles to employing non-Jersey persons. $39 \%$ of the population has a British background and $6 \%$ a Portuguese/Madeira background, that is those employed traditionally in the tourist industry (Etat Civil Committee, 2002).

According to the Jersey Manpower Survey of June 2000 (Policy and Resources Department, 2000a), $8.7 \%$ of positions or jobs are unfilled. Comparing the rate of vacancies between sectors, the construction industry has an $8.5 \%$ vacancy rate to total 
number of positions (the sum of those employed and vacant positions), the same as for the financial sector. The fact that the construction industry vacancy rate is at the same level as that of Financial Services indicates that similar explanations apply for both. The overall limited labour market, together with the high living costs and the protective nature of the island legislation in terms of housing and recruitment could be contributory factors for all Jersey sectors. But employees are leaving the construction industry for other sectors, indicating sectoral influences as well.

Our interviews indicated a high rate of employee turnover in a majority of firms. These retention problems of both employees and apprentices can be largely attributed to employment and working conditions. In total only 12 out of 30 employee/trainee interviewees had been with just one employer over the last five years. Employees are either leaving to other construction firms, or out of the industry altogether. Those who leave do so because they consider employment and working conditions to be substandard in terms of remuneration (no sick pay, no holiday pay, only pay when there is work, late payment), conditions on site (lack of health and safety standards) or development (no training as such). While wages in construction in Jersey have increased, they remain far below the financial sector average. In 1999 average weekly earnings in the Jersey construction sector were $£ 409$ compared with the financial mediation sector with an average of $£ 506$ (Policy and Resources Department, 2000a). Potential recruits are deterred by this relatively low pay, coupled with the lack of a clear career or path of progression within the industry and deteriorating conditions, including skill standards and dirty work. Both recruitment and employment practices are governed by informality, with only minimal standards enforced. The group of companies we interviewed included 
several "good-practice" employers where conditions were considered to be good by their employees. But the employee interviews revealed that conditions with other employers, not part of the sample (including many smaller companies), left a lot to be desired. This was also acknowledged by several key players interviewed: only larger firms and a minority of "good practice" employers (of which there were several in this sample) provide reasonable conditions. The lack of appropriate legislation in this area is seen as requiring rectification. At the moment, only health and safety regulations can be used to make a case for improving conditions.

Job security and decent employment and working conditions were also indicated as reasons for staying with a firm, even if other employers offered higher wages. "Loyalty", "trust", "ability to communicate" and "care" were terms used by several interviewees with respect to their employers. Retention is nevertheless a problem even with this set of firms because of an overstretched and limited labour force, leading to the "poaching" of employees/ apprentices. As a result employers claim that the costs of training people may be lost. Evidence was found of firms (including in the public sector) consciously not investing in initial training in order to be in a financially stronger position to poach apprentices nearing completion of their training (Marsden, 1995). This leaves some Jersey employers reluctant to train or to reduce the transferability of the training offered so that it is geared to more firm-specific skills. Others see providing training as a risk that needs to be taken, as skills shortages are so desperate and training is considered one of the only options for recruitment. Next to its effect on training, "poaching" may lead to an upward wages spiral but this is as yet not particularly significant. 
You get bribed into paying higher wages. If someone threatens to leave, you panic, because you know you're not able to get a replacement. (contractor) Since 1998 earnings in the construction sector have increased by $10.2 \%$, that is more than the average of 7.7\% (Policy and Resources Department, 2000a).

\section{Problems and possible solutions}

Problems with recruitment and retention exacerbate high levels of skill shortages, although the exact extent of these is difficult to estimate. In the Jersey Employers' Survey (2000), $75 \%$ of all employers in construction and manufacturing stated that at least some of their employees have shortcomings in at least one field. Skill problems were reported by all interviewees (employers, employees, key players and, to a lesser extent, apprentices) related to all trades and construction professions at every level (from labourers to professionals), indicating a clear failure of the labour market to train. The employees for example listed as the most prominent problems: lack of knowledge, training and qualification of carpenters and joiners; lack of confidence and competence due to inexperience; and shortage of skilled people in every trade area and of broadly skilled individuals. To the related question of whether there is a lack of suitable people in their field, twenty employees responded affirmatively. Next to the blanket skills shortages for crafts and professions, the lack of managerial and communication skills was seen as important both for professionals and manual workers in supervisory positions to plan the work and relate to colleagues and clients. Several interviewees considered that the appropriate training on the island in these fields was either non-existent or too general to be suitable for construction-related situations. 
The employment of unskilled workers (17\% of operatives) in construction in Jersey is relatively high and appears even to be increasing, given the degree of skill shortages. This is of concern as the construction sector increasingly requires a high skills base adaptable to transformations in work practices and technological advances (Clarke \& Herrmann, 2001; Salzman, 1998). In terms of work practices there has been a dramatic decline in wet trade and labourer employment in the construction industry in Europe and an increase in occupations related to the use of concrete, steel, drylining, prefabricated components and specialist assembly. In countries such as Germany, training covers all areas of work and seeks to produce highly skilled construction workers, able to plan, coordinate and undertake work on their own. The aim is to eliminate labouring work, achieve an entirely skilled labour force and reduce supervision levels (Clarke \& Wall, 1998b).

Skill shortages and unpredictable skill levels of the workforce adversely affect the productivity of the industry (Clarke \& Wall, 2000). There is evidence of less labourintensive activities throughout UK industry (Marsden, 1995; Gallie, 1996). Skill shortages also increase the cost of employing skilled workers (Haskel \& Martin, 1996). Projects cannot be resourced with an adequate supply of skilled labour, construction costs rise, supervision increases, accidents may occur and delays ensue, reducing productivity and further increasing costs. Highly skilled operatives and professionals may also leave the industry, resulting in a waste of training and other resources.

Getting skilled people is problem. The lure of the finance industry is great: it sounds more glamorous and the wages are higher. This goes for manual and professional staff. I met a couple of guys last month that are chartered surveyors 
and did there job well, but were also doing a night class for IT to get into the finance sector. (employer)

There is evidence from our surveys and from the high level of vacancies in construction that a downward spiral has set in. Firms reported low productivity, lower quality of workmanship and high amounts of repeat work. The poor employment and working conditions of the Jersey construction industry militate against attracting a highly skilled workforce. Improved productivity, employment and working conditions though cannot be obtained by "poaching" but only by a larger investment in training at home. The most effective means is to regulate the labour market at the same time as training the workforce to a very high skill level so that the construction process becomes significantly more productive and the proportion of labourers and unskilled is drastically reduced. The current high labour intensity of the process acts as a considerable constraint on building activity generally and on building costs. This is a problem equally evident in the UK, where building output per inhabitant on an index of 100 is 50 compared with 100 for Denmark, 90 for Germany and 77 for the Netherlands (Euroconstruct, 2000).

To remedy the situation of local "poaching" in Jersey a new training framework should be installed in which apprentices are not primarily seen as employees gaining firmspecific skills but trainees equipping themselves with high level and transferable skills to work in the industry as a whole and not for one particular firm. This new training framework requires an overall and long-term vision, incorporating the needs of both industry and society, of government, employers, employees and apprentices, each of which is divergent. Many employers and key players commented on the lack of an overall 
plan for training in Jersey, with clear strategic aims and pragmatic objectives in which all involved agencies play a different but complementary role. Most of the apprentices and some of the employees were unclear about: the nature of their training and/or the type of qualification they are either training for or have obtained and the options available. Employers were largely unaware of the overall performance of their apprentices, the maximum time left in their training and the administrative tasks that have to be done by themselves or the apprentice for training and funding purposes.

Whilst employers' skill needs are often short-term and job specific, employees require skills that are sufficiently broad-based to allow for development, enrichment and transferability over, if possible, a working life. Such a framework is best developed and organised through a social partnership of employers and employees and with state support. For training policy to be beneficial for all actors in the long run, it cannot be left to its own reactions, inevitably more short-term in nature. A long-term policy framework therefore needs regulation for it to transcend its voluntary and short-term character and to guide the long-term dynamic (Boyer, 1987). Next to regulation, an appropriate training framework also needs to have an institutional component:

In a regulatory system, firms must be monitored to ensure they fulfil their training obligations, providing training of a type and quality congruent with the objectives of the policymaker - who should allow for the interests of workers and other firms, as well as the firm providing the training. (Stevens, 1999)

This training structure could be funded by a levy system, which should greatly facilitate the introduction of a training scheme appropriate to Jersey conditions and the attainment 
of transferable skills. It has the advantages of: widening participation, commitment and involvement in construction training; cementing links between industry, education and the TEP; deterring poaching; improving the recruitment base and introducing more formal procedures; facilitating the setting up of a workshop through consultation with Highlands to run specific one-off courses in, for instance, advanced methods; assisting firms in the funding of trainees during their block-release college periods and in sending employees and/or trainees abroad for attendance on short specialist courses; and helping to give the industry its own identity as an innovative, improved and safe sector.

The apprenticeship scheme as it stands is failing to replenish skills in the industry, training requirements are changing with more advanced construction methods, needing more abstract skills that can only be imparted in a classroom and workshop environment. The traditional apprenticeship based on learning on the job from a craftsman, day release to college, and the goodwill and patronage of the individual employer is increasingly obsolete in the modern construction process.

To address the overall problem of skill shortages and the inadequacy of existing skills an extension and intensification of initial and further training and greater adult provision are therefore required in Jersey. Furthermore, in so far as transferable skills are most suited to the needs of Jersey, the training should incorporate simulated workshop-based work experience and group training to allow trainees a range of work experience in different firms. This is similar to the training corporation scheme in the Netherlands where trainees are taken on in the first place by the corporation consisting of groups of employers and then rotated around the different member firms so as to gain a wide experience of work. 
This system relies less on informal networks and individual employer's decisions and more on the joint decision-making and formal procedures of the training corporation. Any training framework also needs to provide a structured system of progression to site management or advanced levels. Combined with skills certification, facilitating formal recognition of qualified tradespeople, this would lay the infrastructure for upgrading skills in the industry.

\section{Conclusion}

Jersey's attempt to remain insular in terms of sustaining the current levels of population is incompatible with its lack of regulation and investment in vocational training. On the one hand, importing skilled labour, tradespeople and professionals fails to improve productivity, employment and working conditions and methods of production. On the other hand, indigenous skilled operatives and professionals are scarce and the already high proportion of the unskilled employed is rising.

The main problems discovered in Jersey relate to the unavailability and inappropriateness of skills, the non-viability of current training and recruitment policies on the island, the fragmentation of the training infrastructure and the questionable sustainability of the local construction industry. Current shortages and the narrow focus of skills, the demanddriven and task- or job-specific nature of training, the Jersey-born and male focus of recruitment and the uncoordinated, traditional and short-term approach of the local construction industry towards promotion and financing of training provision were found to be working against the industry's long-term needs and restricting its ability to respond to the variability of the production process. In contrast, a structured training policy 
incorporating the needs of both education and industry (employee and employer) and holding a long-term vision should enable the construction industry of Jersey, to reverse the downward spiral. Such a downward low-skills spiral is not confined to Jersey but is also observable in the UK. The example of Jersey is however significant in being sufficiently contained to show how such a spiral occurs and how a low-skill equilibrium might be reversed. More than this, it points to the failings of the traditional apprenticeship system, the problems these give rise to and the need for a new concept and regulation of training to produce a highly- and broadly-skilled workforce in tune with the modern construction process.

The question raised is how far an alternative training framework for Jersey to upgrade the current skills base and to climb out of its current low skills equilibrium is not also suitable for the UK - given the similarities between the two labour markets. The choice in both is between further dilution of the skills base, high labour intensity and lower productivity for the industry or creating a new training infrastructure, improving employment and working conditions, a more highly skilled workforce and higher productivity. This latter option implies, as we have shown, significant regulation, in particular of employment but also to increase training provision, to implement a formal structure and framework for training and a training levy, and to expand the recruitment base. In effect, the choice is not simply to import the skills required, even if this were possible given accommodation constraints. It is between regulation and non-regulation. 


\section{References}

Arkani , S., Clarke L. \& Michielsens E. (2001) Construction skills audit and training needs analysis - Final Report. Channel Island of Jersey: Training and Employment Partnership.

Benko, G. \& Lipietz, A. (1998) From the regulation of space to the space of regulation, Geo Journal, 44, 4, pp. 275-281.

Boyer, R. \& Saillard, Y. (eds) (2002) Régulation Theory: the state of the art. London: Routledge.

Boyer, R. (1987) La Theorie de la régulation: une analyse critique. Paris: Editions la Découverte.

CITB (2002) Trainee Numbers Survey. Bircham Newton: CITB.

Clarke, L. \& Herrmann, G. (2001) Innovation and Skills: a transnational study of skills, education and training for prefabrication in housing. London: University of Westminster.

Clarke, L. \& Wall, C. (2000) Craft versus industry: the division of labour in European housing construction, Construction Management and Economics, 18, 6, pp.689-698.

Clarke, L. \& Wall, C. (1998a) A blueprint for change: Construction skills training in Britain. Bristol: Policy Press.

Clarke, L. \& Wall, C. (1998b) UK construction skills in the context of European developments, Construction Management and Economics, 16, pp. 553-567.

Department of Employment and Social Security (1999) Fair Play in the Workplace Good Employment Practice in Jersey. Channel Island of Jersey: States of Jersey.

Education Department (States of Jersey) (1998) Five-Year Strategy Plan for the Jersey Education Service 1993-1998. Channel Island of Jersey: States of Jersey.

Etat Civil Committee (States of Jersey) (1997) Report on the 1996 Jersey Census. Channel Island of Jersey: States of Jersey.

Etat Civil Committee (States of Jersey) (2002) Report on the 2001 Jersey Census. Channel Island of Jersey: States of Jersey.

Eurostat (1997) European Labour Force Survey - figures 1996. Luxembourg: Office for Official Publications of the European Communities.

Euroconstruct (2000) European Construction Trends: The prospects for construction in Europe to 2002. London: Euroconstruct. 
Fielden, S., Davidson, M., Gale, A. \& Davey, C. (2000) Women in Construction: the untapped resource, Construction Management and Economics, 18, pp. 113-121.

Finegold, D. \& Soskice, D. (1988) The Failure of Training in Britain: analysis and prescription, Oxford Review of Economic Policy, 4, 3, pp. 21-53.

Gallie, D. (1996) Skill, Gender and the Quality of Employment, in Crompton, R., Gallie, D. \& Purcell, K. (Eds.) Changing forms of employment. London: Routledge.

Haskel, J. \& Martin, C. (1996) Skill Shortages, Productivity Growth and Wage Inflation, in Booth, A. \& Snower, D. (Eds.) Acquiring Skills: Market Failures, their Symptoms and Policy Responses. Cambridge: Cambridge University Press.

Industries Committee (1999) Regulations of Undertakings and Development (Jersey) Law (1973) (as amended) Policy Statement (with effect from October 1999). Channel Island of Jersey: States of Jersey.

Jersey Employers' Survey (2000) Extra Analyses Manufacturing/Construction Sector. Channel Island of Jersey: Training and Employment Partnership (unpublished).

Keep, E. \& Mayhew, K. (1999) The assessment: knowledge, skills, and competitiveness, Oxford Review of Economic Policy, 15, 1, pp. 1-15.

Marsden, D. (1995) A phoenix from the ashes of apprenticeship? Vocational training in Britain, International Contributions to Labour Studies, 5, pp. 87-114.

Michielsens, E., Wall, C. \& Clarke, L. (1997) A Fair Day's Work - Women in the Direct Labour Organisations, London: London Women and Manual Trades and Manchester: Association of Direct Labour Organisations.

Office for National Statistics (ONS) (1996) Labour Force Survey 1996 UK. London: HMSO.

Office for National Statistics (ONS) (2001) Labour Force Survey 2001 UK Spring quarter (own calculations). (Material from the Labour Force Survey made available through the Office of National Statistics and the ESRC Data Archive has been used by permission of the Controller of H.M. Stationery Office.)

Policy and Resources Committee (States of Jersey) (1999) P94/99, Committees of the States: Reorganisation - Industries Committee, 6/06/1999. Channel Island of Jersey: States of Jersey.

Policy and Resources Department (States of Jersey) (2000a) Report on the Manpower Survey, June 2000. Channel Island of Jersey: States of Jersey.

Policy and Resources Department (States of Jersey) (2000b) Manpower Survey raw data 1996-2000. Channel Island of Jersey: States of Jersey. 
Richter, A. (1998) Qualifications in the German construction industry: Stocks, flows and comparisons with the British construction sector, Construction Management and Economics, 16,5, 581-92.

Salzman, H. (1998) Restructuring and Skill Needs: Will Firms Train?, Annals American Academy (AAPSS), 559, pp. 125-140.

Steedman, H. (1998) A Decade of Skill Formation in Britain and Germany, Journal of Education and Work, 11, 1, pp. 77-93.

Stevens, M. (1999) Human Capital Theory and UK vocational training policy, Oxford review of economic policy, 15, 1, pp. 16-32.

Toner, P. (2000) Trade Apprenticeships in the Australian Construction Industry, Labour \& Industry, 11, 2, pp. 39-58. 
Figure 1

The States of Jersey and the institutional framework of construction industry representation

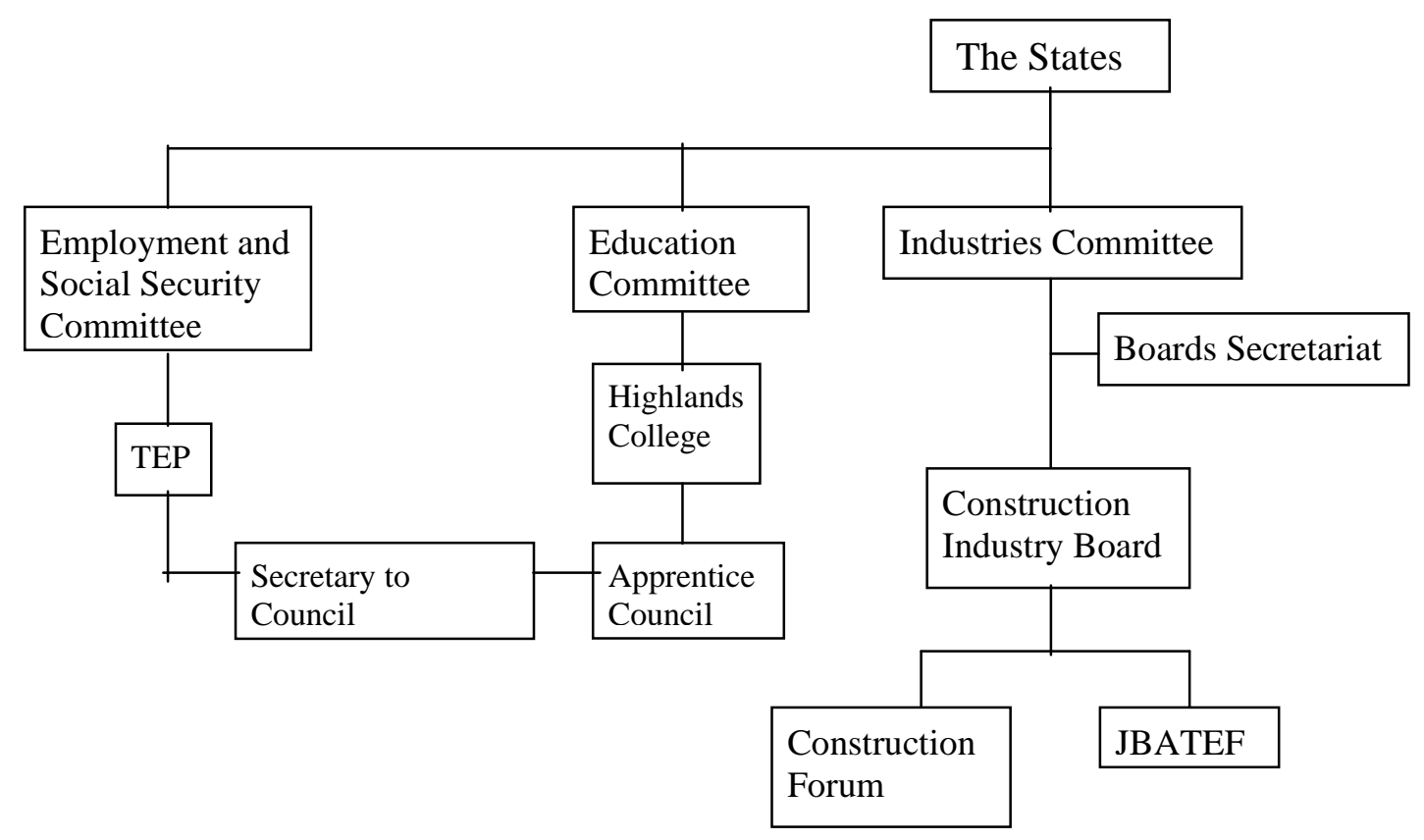

